\title{
Deposition of shells modify nutrient fluxes in marine sediments: effects of nutrient enrichment and mitigation by bioturbation below mussel farms
}

\author{
Per Bergström*, Ylva Durland, Mats Lindegarth \\ Department of Marine Sciences University of Gothenburg, 40530 Gothenburg, Sweden
}

\begin{abstract}
Farming of extractive species such as filter feeding bivalves has been proposed as a potential method to mitigate impacts of eutrophication in marine environments. For such efforts to be sustainable, potential negative effects from mussel farms, such as accumulation of biodeposits in sediment below them, need to be considered and addressed. Benthic burrowing macrofauna strongly influence biogeochemical processes in soft bottom marine habitats by sediment reworking and irrigation and, thus, have the potential to mitigate some of the negative impacts. However, not all biodeposits are organic matter; shells that accumulate on and in the sediment below mussel farms also have the potential to influence processes in the sediment, the activity of bioturbators and the fluxes across the sediment-water interface. In this study, we evaluated the mitigation potential of the bioturbating polychaete Hediste diversicolor in sediments enriched with mussel waste material and the relative impact of mussel shells within the sediment matrix. The polychaetes generally increased fluxes and sediment oxygen uptake. With an observed tendency of increased fluxes of nutrients in sediments containing shells compared to sediments without, the results indicate that the accumulation of shell has a potential to further increase the mitigative effect of the polychaetes by influencing the solute fluxes across the sediment-water interface.
\end{abstract}

KEY WORDS: Shells $\cdot$ Bioturbation $\cdot$ Mussel farming $\cdot$ Mitigation $\cdot$ Nutrient fluxes

\section{INTRODUCTION}

In the last century, the supply of organic material and associated nutrients to coastal environments has increased considerably as a result of human activities (Nixon 1995). The increased levels of nutrients are largely a product of land-based activities such as agricultural fertilization and combustion of fossil fuels (Cloern 2001, Kemp et al. 2005). Several measures have been proposed as potential ways to mitigate the increased nutrient levels and the consequences (e.g. reduced input from land, binding phosphorous into sediment, removal of active top layer of sediment, etc.) (HELCOM 2007, Rydin et al. 2017). Mitigation of eutrophication and its consequences does not necessarily result in a return of the ecosystem to its pre-

\footnotetext{
${ }^{*}$ Corresponding author: per.bergstrom@marine.gu.se
}

vious state (Duarte et al. 2009) but does, potentially, contribute to the rehabilitation of important ecosystem services and functions (Choi 2007).

One proposed measure for abatement of eutrophication in coastal waters is farming of nutrient extractive species such as seaweed or filter feeding bivalves (Lindahl et al. 2005, Petersen et al. 2014, Kotta et al. 2020). Farming of mussels is proposed to remove nutrients from the marine environment based on a mass balance perspective on a water body level. Mussel farming does not only remove nutrients when harvesting but also has positive general effects such as reducing seston concentrations (Petersen et al. 2008, Cranford et al. 2014) and improving water clarity (Schroder et al. 2014). Not all effects of mussel farming, however, are positive. Negative effects such

() The authors 2020. Open Access under Creative Commons by Attribution Licence. Use, distribution and reproduction are unrestricted. Authors and original publication must be credited. 
as increased sedimentation of organic matter below farms may increase oxygen consumption and affect both the sediment chemistry and fauna composition of the benthos (Mattsson \& Lindén 1983, Richard et al. 2007, Carlsson et al. 2009, 2012). Increased flux of organic matter from the farm to the sediment surface supports fluxes of dissolved oxidants to the sediment from the overlying water (Christensen et al. 2003). In combination with limited renewal of bottom water, enhanced supply of organic material may reduce oxygen levels to below the concentration at which biomass and diversity of benthic macrofauna are reduced or completely depleted (Diaz \& Rosenberg 2008). Sediments play a crucial role in biogeochemical cycling in marine environments (Laverock et al. 2011), and consequently, impacts from mussel farming practices can potentially play an important role in the entire ecosystem. The magnitude of the impacts on benthic habitats is dependent on a complex interaction of many factors including mussel density and environmental conditions such as water exchange and sediment type (Burkholder \& Shumway 2011). The capacity of a benthic system to deal with such input of organic matter and to mineralize biodeposits is critical to determine the magnitude of negative effects of mussel farms.

Through their sediment reworking and irrigation, benthic macrofauna strongly alter the distribution of sediment particles, solutes and microbial communities (Meysman et al. 2006), thus directly and indirectly affecting the decomposition, remineralisation and preservation of organic matter in sediments (Aller 1994, 2001, Aller et al. 2001, Reise 2002). Bioturbating polychaetes have the potential to stimulate decomposition of organic material and couple nitrificationdenitrification by their reworking of the sediment, which increases the assimilative capacity of the sediment (Gilbert et al. 2003). Their reworking can also contribute to the creation of favourable conditions for alternative pathways for nitrogen and metal redox coupling (Hulth et al. 2005). Fluxes of nutrients and oxygen across the sediment-water interface have been observed to increase 2.5-3.5 times in bioturbated sediments compared to non-bioturbated control sediments (Tuominen et al. 1999, Kristensen 2000, Howe et al. 2004, Norling et al. 2007). It is generally accepted that the most important role of bioturbation is the stimulation of remineralization reactions by introducing oxygen into the sediment surface, which has the potential to increase decomposition of organic matter 10-fold (Heilskov \& Holmer 2003, Kristensen \& Kostka 2005, Valdemarsen et al. 2010). However, this increased metabolic capacity is not always observed under high organic load (CasadoCoy et al. 2020). One common bioturbator in coastal soft sediments is the ragworm Hediste diversicolor. $H$. diversicolor influence physical, chemical and biological properties of the water-sediment interface mainly through their sediment reworking, e.g. the construction of a dense gallery of burrows, and by bioirrigation (Mermillod-Blondin et al. 2004). Gallery diffusers like $H$. diversicolor have been shown to increase uptake of nitrate in the sediment while increasing the efflux of ammonium and phosphate by stimulating microbial processes. This favours an influx of oxygen and nitrate from the overlying water into anoxic parts of the sediment simultaneously, stimulating organic matter oxidation (Aller 1994). However, the effect of macrofauna on solute fluxes depends not only on the species involved, its density and total biomass, but also its interactions with the community (Michaud et al. 2005, Caliman et al. 2007). Information on how bioturbation activities are modified by biotic and abiotic habitat characteristics is sparse but increasing (Meysman et al. 2006, Bernard et al. 2019).

Not all biodeposits from mussel farms are organic matter; a large component of the biodeposits that reaches the seafloor is shells. The calcareous shells of molluscs in various states of decomposition are important elements in the habitat structure, introducing complexity and heterogeneity (Gutierrez et al. 2003). High densities of shells in sediments create a matrix, which stabilizes surface sediment and changes flow patterns at the sediment-water interface (Reise 2002), effecting nutrient fluxes (Hewitt et al. 2005). The size of these effects is influenced by the shape of the shells and their properties such as convexity and surface roughness (Olivera \& Wood 1997, Denny \& Blanchette 2000). Furthermore, shells may influence the structure and functioning of benthic assemblages. The increased habitat complexity caused by shell and shell-hash could promote denitrification, which, potentially, also increases the ammonium release to the water column under organic pollution (Casado-Coy et al. 2017). CasadoCoy et al. (2017) also show that polychaetes pronounce the effects of shell-hash. Many bioturbating species have the ability to switch between deposit and suspension feeding, depending on, among other things, the grain size of the sediment, particle concentration in the water and water movement (Riisgård \& Kamermans 2001). The polychaete $H$. diversicolor is one such species (Riisgard 1991, Evrard et al. 2012), suggesting that introduction of shells to the sediment might affect bioturbation. It has also been 
shown that $H$. diversicolor not only stimulates decomposition of organic material under mussel farms (Bergström et al. 2017) but it is also able to utilize the faeces and pseudofaeces on the bottom beneath mussel farms as a food source (Bergström et al. 2019).

This study investigates how the accumulation of shells in sediment under mussel farms may affect the potential of using polychaetes to mitigate the negative impacts of the organic matter from the farm and to what extent the shells themselves contribute to this impact. In order to simulate this under controlled conditions, we conducted a laboratory experiment using mussel farm sediment, blue mussel shells, mussel biodeposits and $H$. diversicolor, and measured the sediment oxygen consumption and nutrient fluxes across the sediment-water interface over a $24 \mathrm{~d}$ period.

\section{MATERIALS AND METHODS}

\subsection{Field collection and experimental design}

The experiment was conducted at Tjärnö Marine laboratory at Koster Fjord on the Swedish west coast during the autumn of 2019. Sediment was collected at $15 \mathrm{~m}$ depth at a nearby mussel (Mytilus edulis) farm $\left(58^{\circ} 32.22^{\prime} \mathrm{N}, 11^{\circ} 5.16^{\prime} \mathrm{E}\right)$. The sediment was homogenized by removing stones, shells and living organisms using a $2 \mathrm{~mm}$ mesh sieve prior to experimental setup, and the organic content was measured in triplicates. The homogenized sediment (silt/clay $45 \%$, sand $55 \%$ ) was divided into 2 parts. The first part of the sediment was left as a sediment only (-Shell) sediment and the other second half was mixed with cleaned mussel shells and fragments in a 2:1 (sediment:shell) ratio based on volume as a shell sediment (+Shell). The experimental cores (inner diameter $95 \mathrm{~mm}$, height $33 \mathrm{~cm}$ ) were allocated randomly and semi-filled with one of the 2 sediment types. The cores were placed in a tank (Fig. 1), which was filled to $\sim 15 \mathrm{~cm}$ with flowthrough seawater to reduce temperature fluctuations in the sample cores by reducing the potential for fluctuations caused by daily air temperature changes and at the same time insuring that all cores kept the same temperature. Each core was supplied with continuous flow through seawater $\left(\sim 10 \mathrm{ml} \mathrm{min}{ }^{-1}\right)$, and the sediment cores were rested for $24 \mathrm{~h}$ to settle. The cores were divided into 4 treatments per sediment type: with and without polychaetes (+Polychaete vs. -Polychaete), with and without addition of organic matter (+OM vs. $-\mathrm{OM})$ and their combinations. There were 6 replicates per treatment combination, distributed over 2 sampling times ( 3 replicates per treatment and time) for a total of 48 cores. An additional 6 cores were prepared (3 of the combination +Shells, -Polychaetes, $-\mathrm{OM}$; and 3 of the combination -Shells, -Polychaete, $-\mathrm{OM})$ for pre-treatment sampling $\left(T_{0}\right)$ of the system stability and performance. Approximately 100 individuals of Hediste diversicolor were collected by sieving sediments (mesh size $2 \mathrm{~mm}$ ) from a nearby shallow location (Fig. 1) $48 \mathrm{~h}$ before the start of the experiment and acclimated under similar conditions as in the experimental cores until the start of the experiment $\left(T_{0}\right)$. For treatments with polychaetes, a

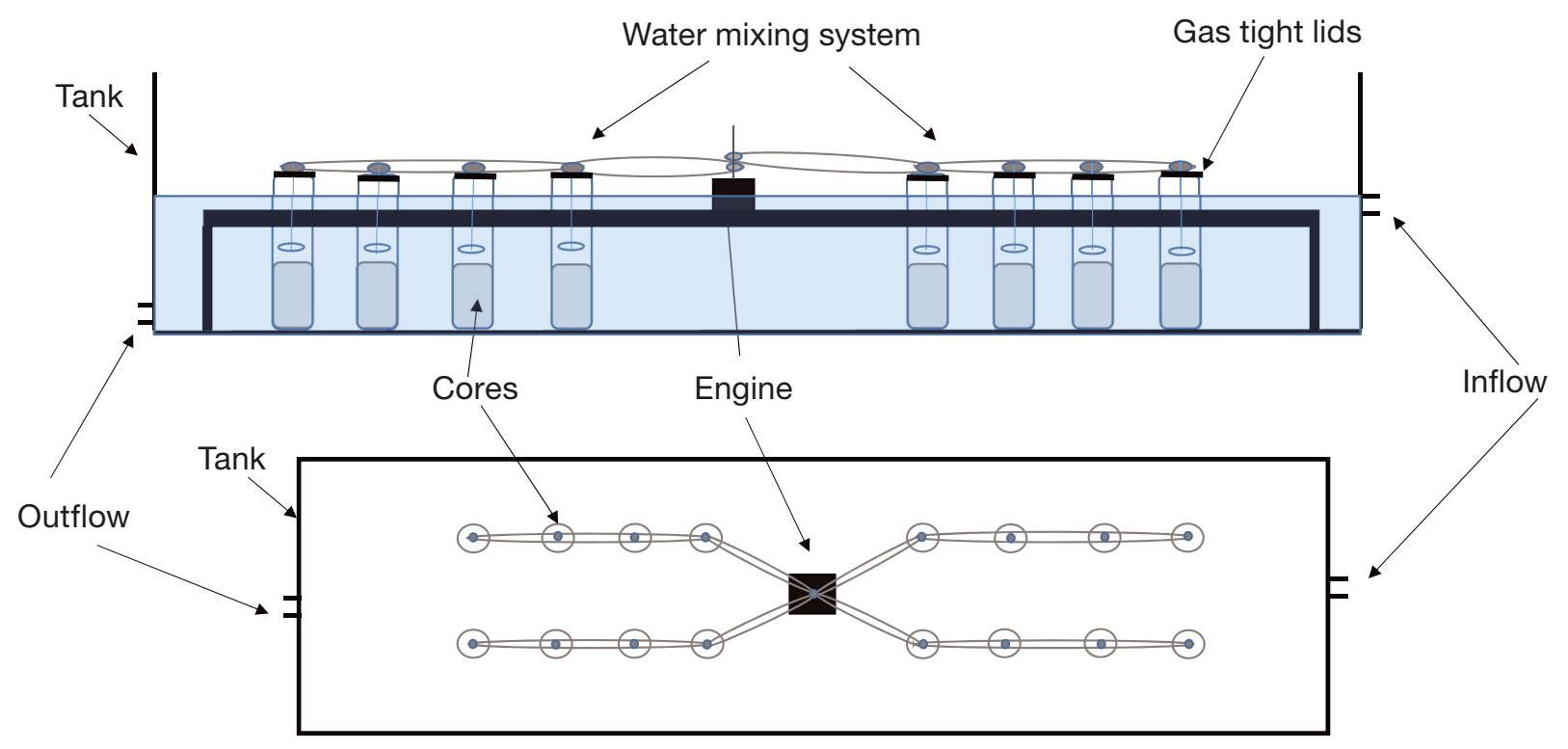

Fig. 1. Schematic illustration of tank and experimental system 
group of 3 pre-weighed individuals $(1.20 \pm 0.18 \mathrm{~g}$ per sample) were randomly added to the cores. This resulted in a density of $\sim 423$ ind. $\mathrm{m}^{-2}$, which is well within the range of observed natural densities (0-2560 ind. $\mathrm{m}^{-2}$; Nielsen et al. 2004). Mussel wastes were collected from the bottom of tanks in which live mussels were kept on nets $\sim 20 \mathrm{~cm}$ above the bottom of the tanks in the laboratory. The mussels were fed using the naturally occurring plankton population through flow-through of seawater, and the deposits were dried, subsampled and the organic content measured in triplicate. Organic biodeposit amounts used in the experiment were based on literature values on sedimentation rates (1.6-2.5 $\left.\mathrm{g} \mathrm{C} \mathrm{m}^{-2} \mathrm{~d}^{-1}\right)$ from a Swedish mussel farm (Carlsson et al. 2012) and on the organic content of the collected mussel biodeposits. Addition of biodeposits, corresponding to a sedimentation rate of $2.3 \mathrm{C} \mathrm{m}^{-2} \mathrm{~d}^{-1}$, were performed every third day during the experiment. Sampling was done using an initial sampling at the start of the experiment $\left(T_{0}\right)$ and a hierarchical design with samples after 1 and $3 \mathrm{wk}$ $\left(T_{1}\right.$ and $\left.T_{2}\right)$, respectively. At each sampling point, 3 cores from each treatment were sampled for nutrient fluxes, sediment oxygen uptake (SOU) and organic content of the sediment. All cores were discarded after sampling, and no cores were sampled more than once. The behaviour and performance of the polychaetes were measured as the change in weight and by the number of holes dug in the sediment.

\subsection{Flux measurements using core incubations}

In order to estimate nutrient and oxygen fluxes across the sediment-water interface, we measured nutrient and oxygen concentrations in the seawater before and after a $6 \mathrm{~h}$ incubation period, corresponding to $\sim 15-20 \%$ change in oxygen concentration. Sampling consisted of measurements of oxygen (WTM multi 3420 equipped with a Dissolved Oxygen Sensor FDO ${ }^{\circledR}$ 925-3, precision $\pm 0.5 \%$ of value) and water samples $(20 \mathrm{ml})$. Initial samples were taken immediately prior to sealing the cores for incubation and final samples at the end of incubation after which the cores were discarded. The water samples were filtered and frozen until analysis by segmented flow analysis (QuAAtro, XY-3 Sampler, Seal Analytical 2015) for dissolved nutrients $\left(\mathrm{NH}_{4}{ }^{+}, \mathrm{NO}_{3}{ }^{-}, \mathrm{NO}_{2}{ }^{-}\right.$and $\left.\mathrm{PO}_{4}{ }^{3-}\right)$. For incubation a custom-built system was used that allowed for whole cores to be incubated standing in a tank with a flow-through system maintaining in situ temperature $\left(T_{0}: 14.5^{\circ} \mathrm{C}, T_{1}: 14.5^{\circ} \mathrm{C}\right.$ and $\left.T_{2}: 12.9^{\circ} \mathrm{C}\right)$.
Each core was equipped with gas-tight lids, and at the start of the incubation cores were closed to prevent equilibration with oxygen in the surrounding air and the overlying water. The water column was carefully mixed to prevent build-up of concentration gradients using a rotating paddle $(\sim 30 \mathrm{rpm})$ driven by a small electric engine (VEXTA, model GFS5G10) placed in the centre of the incubation system. Benthic fluxes and SOU were calculated as the change in concentration per unit area and time between start and end samples. Finally, samples of the sediment were collected from each core and organic content measured as loss of ignition (LOI).

\subsection{Statistical analyses}

Fluxes were compared between treatment combinations by first assessing data normality graphically and then by Cochran's test before statistically analysing the patterns using standard procedures for ANOVA as described below. The analyses were divided into 3 steps to clearly identify effects of shells in the absence of bioturbation and additions of organic material (Step 1), behaviour of polychaetes and sediment properties (Step 2) and interactive effects of shells, polychaetes and addition of biodeposits (Step 3). To analyse the effects of shell on fluxes across sediment-water interface, we used the samples from the treatments without polychaetes and without additions of organic material from all 3 times $\left(T_{0}, T_{1}\right.$ and $T_{2}$ ) in an ANOVA with shell and time as fixed factors. In Step 2, we analysed change in weight of the polychaetes and the number of holes created as a function of shells, time and addition of organic material (all fixed factors) and graphically investigated the development of organic content in the sediment over time with and without addition of organic material in treatments without shells and polychaetes. Finally, we tested the effects of all experimental treatments and their interactions on the sediment-water fluxes of oxygen and nutrients in Step 3 using ANOVA. Prior to analysis, assumptions of normality of residuals and homogeneity of variances were graphically explored and transformations performed if deemed necessary. With significant non-homogenous variances observed for most flux measurements, all response data were transformed for further analyses. Oxygen fluxes which were all negative (uptake into sediment), were $\log [x \times(-1)]$ transformed, while the nutrient fluxes which displayed both positive and negative values were transformed as $\log [x+|\min (x)|+1]$. These trans- 
formations resulted in homogenous variances as indicated by non-significant Cochran tests.

All statistical analyses were conducted using purpose-built scripts in the statistical package $\mathrm{R}$ (version 3.6.2; R Core Team 2019) and the RStudio desktop interface (R Studio Team 2019) using the standard library complemented by the packages 'agricolae' (de Mendiburu 2019) for the Student-Newman-Keuls (SNK) test and 'outliers' (Komsta 2011) for the Cochran test.

\section{RESULTS}

\subsection{Effects of shells}

The system displayed stability with no significant changes in fluxes of nutrients over time (Tables 1 \& 2). However, the SOU decreased over time (Fig. 2, Table 1). At the start of the experiment, no differences in fluxes between sediments containing shells and those without were observed. The initial effects ( $T_{0}$ to $T_{1}$ ) were small with limited increase in fluxes of

Table 1. ANOVA of sediment oxygen uptake (SOU), sediment-water phosphate fluxes and sediment organic matter (OM) content in non-bioturbated (no polychaetes present) mussel shell-affected sediments without additional OM additions over time. Significant $(p<0.05)$ effects in bold

\begin{tabular}{|c|c|c|c|c|c|c|c|}
\hline \multirow[t]{2}{*}{ Factor } & \multirow[t]{2}{*}{$\mathrm{df}$} & \multicolumn{2}{|c|}{$-\mathrm{SOU}-$} & \multicolumn{2}{|c|}{ Phosphate } & \multicolumn{2}{|c|}{$-\mathrm{OM}=$} \\
\hline & & MS & $\mathrm{p}$ & MS & $\mathrm{p}$ & MS & $\mathrm{p}$ \\
\hline Shell $(S)$ & 1 & 0.023 & 0.53 & 0.046 & 0.17 & 0.113 & 0.15 \\
\hline Time $(T)$ & 2 & 1.82 & $<0.01$ & 0.042 & 0.19 & 0.102 & 0.16 \\
\hline$S \times T$ & 2 & 0.055 & 0.39 & 0.024 & 0.36 & 0.018 & 0.70 \\
\hline Residuals & $12^{\mathrm{a}}$ & 0.055 & & 0.021 & & 0.048 & \\
\hline
\end{tabular}

Table 2. ANOVA of sediment-water fluxes of ammonium, nitrate and nitrite in non-bioturbated (no polychaetes present), mussel shell-affected sediments without additional organic matter additions over time. Significant $(p<0.05)$ effects in bold

\begin{tabular}{|c|c|c|c|c|c|}
\hline \multirow[t]{2}{*}{ Factor } & \multirow[t]{2}{*}{$\mathrm{df}$} & Ammonium & \multicolumn{2}{|c|}{ - Nitrate - } & — Nitrite - \\
\hline & & $\mathrm{MS} \quad \mathrm{p}$ & MS & $\mathrm{p}$ & $\mathrm{MS} \quad \mathrm{p}$ \\
\hline Shell $(S)$ & 1 & $0.064<\mathbf{0 . 0 1}$ & 0.002 & 0.89 & $0.081<\mathbf{0 . 0 1}$ \\
\hline Time $(T)$ & 2 & $0.005 \quad 0.27$ & 0.062 & 0.59 & $0.012 \quad 0.06$ \\
\hline$S \times T$ & 2 & $0.013<\mathbf{0 . 0 5}$ & 0.091 & 0.47 & $0.028<\mathbf{0 . 0 1}$ \\
\hline Residuals & 11 & 0.003 & 0.114 & & 0.003 \\
\hline
\end{tabular}

ammonium, nitrite and phosphate and no changes for the other parameters. A tendency of increased fluxes of nutrients from + Shell sediments compared to -Shell sediments was observed. Even though the analysis showed significant effects of shell, time and their interaction, the levels of OM were similar in the different treatments and stable across the sampling (Fig. 2, Table 1).

\subsection{Polychaete behaviour and sediment properties}

In order to evaluate how the polychaetes respond to the experimental conditions, we assessed the burrowing activity, as indicated by number of visible holes, and weight changes upon experimental completion. During the experiment, only 2 polychaetes died, giving a survival rate of $97.2 \%$. Observations of burrowing patterns showed that in + Shell sediments, the number of polychaete holes was significantly ( $\mathrm{p}<$ 0.01) lower than in -Shell sediments (Table 3, Fig. 3).

Table 3. ANOVA of the change in weight of polychaetes and number of holes created by the polychaetes as function of shell, addition of organic matter (OM) and time. Significant $(\mathrm{p}<0.05)$ effects in bold

\begin{tabular}{|lccccc|}
\hline \multirow{2}{*}{ Factor } & df & \multicolumn{3}{c|}{ No. of holes } & \multicolumn{3}{c|}{ Weight change } \\
& & MS & p & MS & p \\
\hline Shell $(S)$ & 1 & 651 & $\mathbf{< . 0 1}$ & 1001 & $<\mathbf{0 . 0 1}$ \\
OM addition (OM_add) & 1 & 30.4 & 0.19 & 657 & $<\mathbf{0 . 0 5}$ \\
Time $(T)$ & 1 & 70 & 0.06 & 579 & $<\mathbf{0 . 0 5}$ \\
$S \times$ OM_add & 1 & 63 & 0.07 & 2.2 & 0.88 \\
$S \times T$ & 1 & 15.0 & 0.36 & 20.6 & 0.66 \\
OM_add $\times T$ & 1 & 3.4 & 0.66 & 347 & 0.09 \\
$S \times$ OM_add $\times T$ & 1 & 51 & 0.10 & 1.6 & 0.90 \\
Residuals & 16 & 16.6 & & 103.6 & \\
& & & & & \\
\end{tabular}


The polychaete also lost, on average, less weight in + Shell sediments than in -Shell sediments (Table 3, Fig. 3). However, the weight change of polychaetes also changed over time and with different organic loads (Table 3 ). The organic content (LOI) decrease over time when no further additions of OM (mussel biodeposits) were made went from approximately $5 \%$ of sediment dry weight to roughly $4.75 \%$ at the end of experiment, while when biodeposits were added, the content increased to $\sim 5.7 \%$ (Fig. 4).
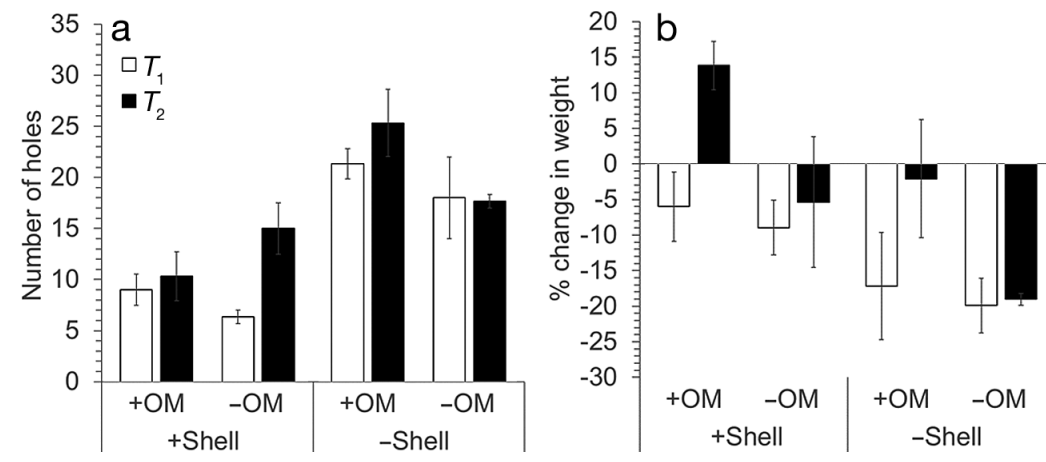

Fig. 3. Effect of presence of shells (+Shell/-Shell) in sediment with different organic matter loads (+OM/-OM) on (a) the number of holes created in the sediment by the polychaetes and (b) the change in weight of the polychaetes at the 2 sampling times: $T_{1}$ : after $1 \mathrm{wk}_{i} T_{2}$ : after $3 \mathrm{wk}$

\subsection{Interactive effects of shells, polychaetes and additions of organic material}

Overall, there were generally higher fluxes in the presence of polychaetes (+Polychaete) and a tendency of decreasing flux over time. SOU ranged from 5.2 to $65.6 \mathrm{mmol} \mathrm{m}^{-2} \mathrm{~d}^{-1}$. In +Polychaete sediment, SOU ranged from $11.4-65.6 \mathrm{mmol}, \mathrm{m}^{-2} \mathrm{~d}^{-1}$, while in sediments without $H$. diversicolor, maximum SOU was $22.6 \mathrm{mmol} \mathrm{m}^{-2} \mathrm{~d}^{-1}$. The minimum SOU did not differ significantly between + Shell and -Shell sediments, but maximum SOU increased by ca. $50 \%$, from $44.6 \mathrm{mmol} \mathrm{m}^{-2} \mathrm{~d}^{-1}$ without shells to $65.6 \mathrm{mmol}$ $\mathrm{m}^{-2} \mathrm{~d}^{-1}$ with shells. SOU was significantly higher in sediments inhabited by polychaetes (Table 4, Fig. 5). SOU was higher at $T_{1}$ compared to $T_{2}$. Shells significantly increased the effect of polychaetes on SOU. However, the 3-way interaction Polychaete $\times$ Time $\times$ OM was complex and complicates straightforward interpretation of the main effects (Fig. 5). Fluxes of phosphate and the effects of treatments showed that there were both significant effects of polychaetes $(p<0.001)$ and shells $(p<0.05)$ increasing fluxes, effects that also were declining over time (Table 4, Fig. 5). Ammonium fluxes from sediment to water were increased by the presence of both polychaetes and shells. Generally, ammonium fluxes decreased with time, and the effects of polychaetes and shells were negatively correlated with time, down to almost negligible levels at $T_{2}$ (Table 5, Fig. 6). There was also a complex 3-way interaction

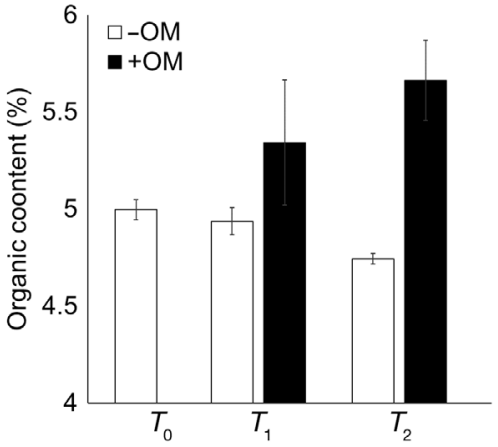

Fig. 4. Effect of addition of organic matter (-OM/+OM), in the form of biodeposits from mussels, on the organic content in the sediment during the experiment. $T_{0}$ : samples at start of experiment; $T_{1}$ : samples after $1 \mathrm{wk}_{;} T_{2}$ : samples after $3 \mathrm{wk}$

Table 4. ANOVA of sediment oxygen uptake (SOU), sediment-water phosphate fluxes and sediment organic matter (OM) content in sediments affected by the experimental treatments. Significant $(p<0.05)$ effects in bold

\begin{tabular}{|c|c|c|c|c|c|c|c|}
\hline \multirow[t]{2}{*}{ Factor } & \multirow[t]{2}{*}{$\mathrm{df}$} & \multicolumn{2}{|c|}{$-\mathrm{SOU}-$} & \multicolumn{2}{|c|}{ Phosphate } & \multicolumn{2}{|c|}{$\mathrm{OM}-$} \\
\hline & & MS & $\mathrm{p}$ & MS & $\mathrm{p}$ & MS & $\mathrm{p}$ \\
\hline Polychaete $(P)$ & 1 & 7.44 & $<0.01$ & 1.485 & $<0.01$ & 0.052 & 0.54 \\
\hline Shell $(S)$ & 1 & 0.18 & 0.19 & 0.27 & $<0.05$ & 0.045 & 0.57 \\
\hline OM addition (OM_add) & 1 & 0.20 & 0.17 & 0.09 & 0.13 & 0.83 & $<0.05$ \\
\hline Time $(T)$ & 1 & 3.93 & $<0.01$ & 0.04 & 0.34 & 1.058 & $<0.01$ \\
\hline$P \times S$ & 1 & 0.62 & $<0.05$ & 0.00 & 0.96 & 0.071 & 0.47 \\
\hline$P \times$ OM_add & 1 & 0.00 & 0.84 & 0.00 & 0.73 & 0.352 & 0.11 \\
\hline$S \times$ OM_add & 1 & 0.03 & 0.58 & 0.02 & 0.46 & 0.214 & 0.22 \\
\hline$P \times T$ & 1 & 0.00 & 0.99 & 0.46 & $<0.01$ & 0.622 & $<0.05$ \\
\hline$S \times T$ & 1 & 0.04 & 0.52 & 0.25 & $<0.05$ & 0.313 & 0.14 \\
\hline OM_add $\times T$ & 1 & 0.02 & 0.64 & 0.02 & 0.50 & 0.03 & 0.64 \\
\hline$P \times S \times O M \_$add & 1 & 0.25 & 0.13 & 0.12 & 0.10 & 0.108 & 0.38 \\
\hline$P \times S \times T$ & 1 & 0.10 & 0.32 & 0.02 & 0.49 & 0.01 & 0.79 \\
\hline$P \times$ OM_add $\times T$ & 1 & 1.50 & $<0.01$ & 0.09 & 0.14 & 0.194 & 0.24 \\
\hline$S \times$ OM_add $\times T$ & 1 & 0.27 & 0.11 & 0.08 & 0.16 & 0.083 & 0.44 \\
\hline$P \times S \times \bar{O}$ M_add $\times T$ & 1 & 0.06 & 0.45 & 0.00 & 0.72 & 0.001 & 0.98 \\
\hline Residuals & $32^{\mathrm{a}}$ & 0.10 & & 0.04 & & 0.134 & \\
\hline${ }^{\mathrm{a}} 30$ for phosphate & & & & & & & \\
\hline
\end{tabular}



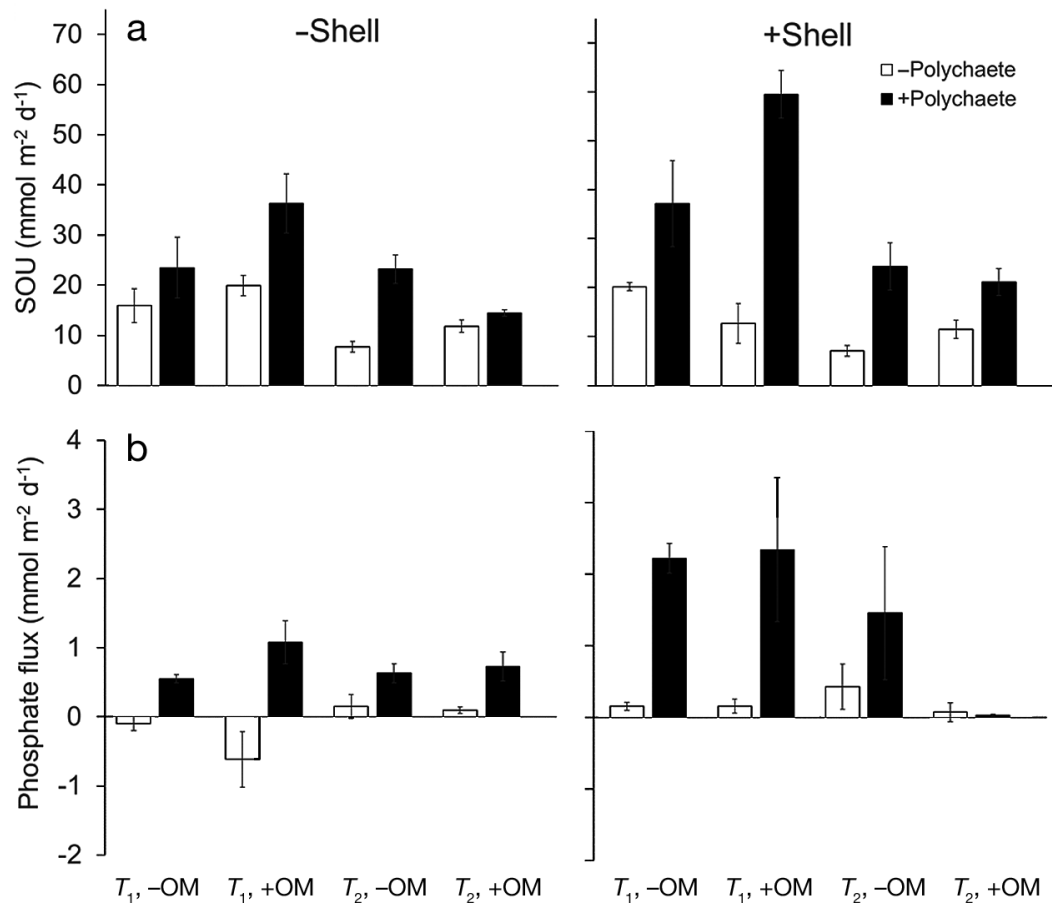

Fig. 5. Effects of shells on (a) sediment oxygen uptake (SOU) and (b) phosphate fluxes in sediments with different organic matter loads (+OM/-OM) and at 2 different sampling times ( $T_{1}$ : after $1 \mathrm{wk}_{;} T_{2}$ : after $\left.3 \mathrm{wk}\right)$ in the presence and absence of polychaetes (-Polychaete/+Polychaete)

Table 5. ANOVA of sediment-water fluxes of ammonium, nitrate and nitrite in sediments affected by the experimental treatments. OM: organic matter Significant $(p<0.05)$ effects in bold

\begin{tabular}{|c|c|c|c|c|c|c|c|}
\hline \multirow[t]{2}{*}{ Factor } & \multirow[t]{2}{*}{ df } & \multicolumn{2}{|c|}{ Ammonium } & \multicolumn{2}{|c|}{ - Nitrate- } & \multicolumn{2}{|c|}{ Nitrite } \\
\hline & & MS & $\mathrm{p}$ & MS & $\mathrm{p}$ & MS & $\mathrm{p}$ \\
\hline Polychaete $(P)$ & 1 & 3.68 & $<0.01$ & 0.25 & 0.35 & 0.04 & 0.14 \\
\hline Shell $(S)$ & 1 & 1.52 & $<0.01$ & 0.09 & 0.58 & 0.12 & $<0.05$ \\
\hline OM addition (OM_add) & 1 & 0.25 & 0.20 & 0.00 & 0.92 & 0.06 & 0.07 \\
\hline Time $(T)$ & 1 & 0.78 & $<0.05$ & 5.00 & $<0.01$ & 0.02 & 0.34 \\
\hline$P \times S$ & 1 & 0.16 & 0.31 & 0.04 & 0.70 & 0.03 & 0.21 \\
\hline$P \times$ OM_add & 1 & 0.13 & 0.37 & 0.11 & 0.54 & 0.03 & 0.17 \\
\hline$S \times$ OM_add & 1 & 0.24 & 0.22 & 0.65 & 0.14 & 0.08 & $<0.05$ \\
\hline$P \times T$ & 1 & 1.79 & $<0.01$ & 0.63 & 0.15 & 0.03 & 0.16 \\
\hline$S \times T$ & 1 & 1.66 & $<0.01$ & 0.03 & 0.74 & 0.17 & $<0.01$ \\
\hline OM_add $\times T$ & 1 & 0.07 & 0.51 & 0.00 & 0.97 & 0.00 & 0.76 \\
\hline$P \times \bar{S} \times$ OM_add & 1 & 0.34 & 0.14 & 0.17 & 0.44 & 0.01 & 0.41 \\
\hline$P \times S \times T$ & 1 & 0.18 & 0.28 & 0.29 & 0.32 & 0.02 & 0.32 \\
\hline$P \times$ OM_add $\times T$ & 1 & 0.13 & 0.35 & 0.01 & 0.84 & 0.00 & 0.81 \\
\hline$S \times$ OM_add $\times T$ & 1 & 0.77 & $<0.05$ & 0.53 & 0.18 & 0.06 & 0.07 \\
\hline$P \times S \times$ OM_add $\times T$ & 1 & 0.01 & 0.77 & 0.01 & 0.83 & 0.01 & 0.56 \\
\hline Residuals & 30 & 0.15 & & 0.29 & & 0.02 & \\
\hline
\end{tabular}

among the factors shell, addition of $\mathrm{OM}$ and time. This can be interpreted to indicate that addition of organic material generally causes an increased ammonium flux, except at $T_{2}$ when shells are present. Instead, after $3 \mathrm{wk}$ of adding organic material to cores with shells, the net ammonium flux is practi- cally reduced to zero, while those with shells but not receiving OM still show high fluxes of ammonium. The treatments had no direct effect on the fluxes of nitrate across the sedimentwater interface, and no significant results were obtained except for a slightly increased efflux of nitrogen at $T_{2}$ compared to $T_{0}$. In contrast to the results from nitrate, addition of shells to the sediment had a significant and positive effect on the efflux of nitrite from the sediment (Table 5, Fig. 6). However, this increased efflux was inhibited by the addition of $\mathrm{OM}$, and the effect decreased over time (Fig. 6).

\section{DISCUSSION}

Burrowing benthic animals have a well-documented stimulatory effect on different pathways of benthic nutrient cycling, through their sediment reworking and ventilation of burrows (Pelegri \& Blackburn 1995, Rysgaard et al. 1995, Stief 2013), which affect, among other things, decomposition and remineralisation. The factors modifying these activities are still poorly understood (Meysman et al. 2006). There are very few studies (e.g. Casado-Coy et al. 2017) on how this stimulatory effect on nutrient cycling is influenced by the interaction between the activity of the polychaetes and accumulation of shells on the sediment surface. Microcosm experiments such as this are only an approximation of natural systems, and thus any conclusions drawn from them should be carefully considered. Nonetheless, these experiments can provide a control of the environmental variables and investigate cause-effect relationships which are otherwise difficult to evaluate. Here we demonstrate that, in sediments impacted by biodeposits from mussel farms, potential mitigation efforts using bioturbating polychaetes are positively enhanced by the presence of mussel shells on the sediment surface and that reducing the accumulation of by-products from anaerobic and aerobic metabolic pathways improves the sediment status. 

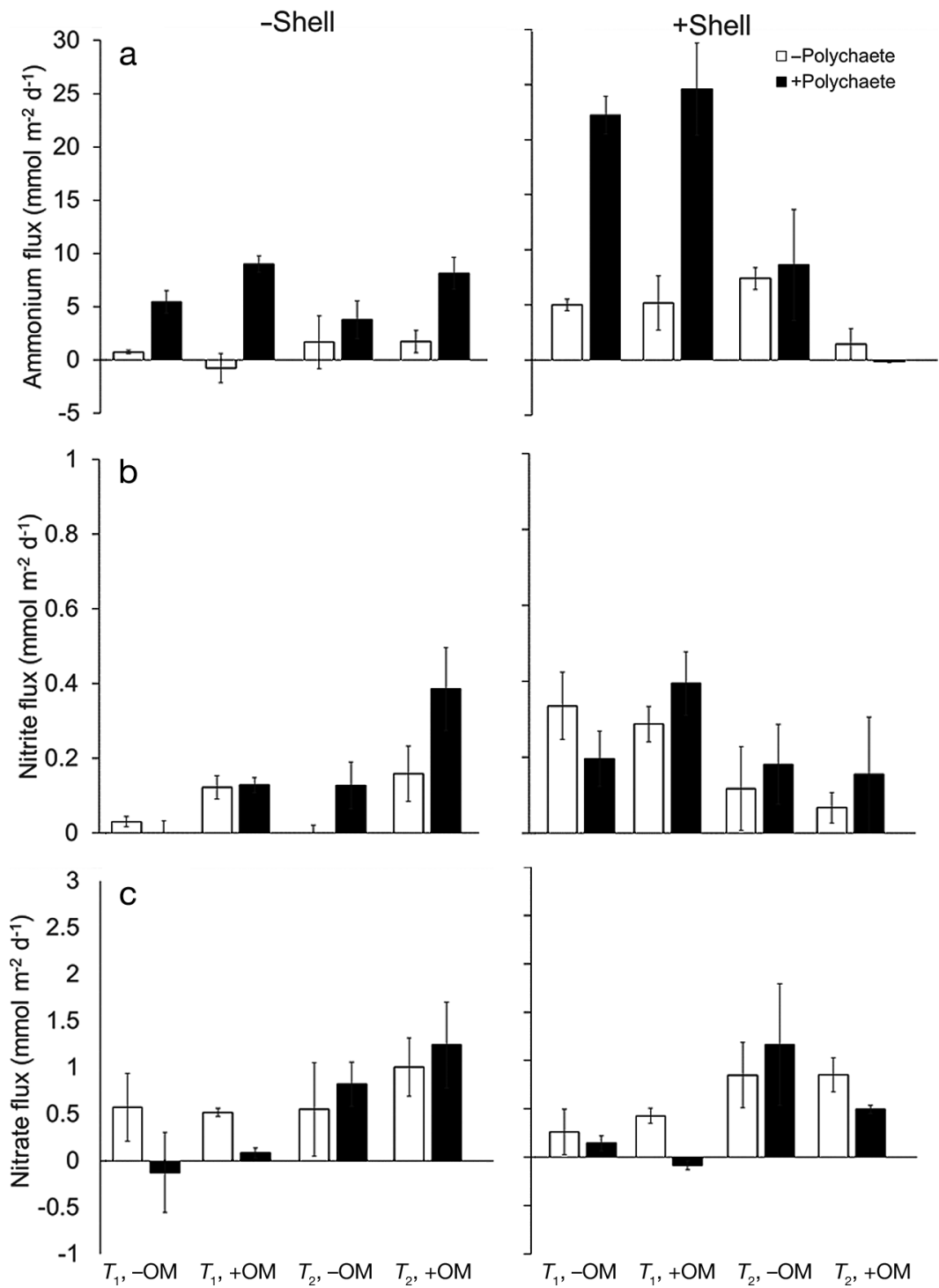

Fig. 6. Effect of shells (-Shell, left column; + Shell, right column) on nitrogen fluxes in sediments at different organic matter loads (-OM/+OM) and at 2 different sampling times ( $T_{1}$ : after $1 \mathrm{wk} ; T_{2}$ : after $3 \mathrm{wk}$ ) in the presence and absence of polychaetes (-Polychaete/+Polychaete). (a) Ammonium, (b) nitrite and (c) nitrate

The importance of bivalve shells in coastal sediment ecosystems is well known (Ragnarsson \& Raffaelli 1999, Reise 2002, Gutierrez et al. 2003, Commito et al. 2008). Here, we show that the accumulation of shells on sediment surface under mussel farms have the potential to further increase the effect of bioturbation by the polychaetes Hediste diversicolor on solute fluxes across the sediment-water interface, thus supporting the idea of using burrowing polychaetes to mitigate sediments impacted by biodeposits from mussel farms. In this experiment, we expected the structure and complexity of microhabitats created by inclusion of mussel shells to favour aerobic degradation of organic matter. These microhabitats could promote the coupling between nitrification and denitrification and thus potentially increase denitrification. This would cause decreased ammonium release rates from sediment without macrofauna to which additions of organic matter were made. However, we did not observe any clear indication of this (denitrification rates not measured) even though at the final sampling there was a lower ammonium release from organically enriched sediments in the presence of shells compared to similar sediments without shells. Furthermore, the shells themselves offer hard surfaces suitable for the developments of bacterial biofilms (Gutierrez et al. 2003), which are hotspots for bacterial activity and thus have an important role in biogeochemical cycling. However, we did observe an increased SOU as an effect of the polychaete's bioturbation. This effect was enhanced by the presence of shells, indicating an increase in the degradation of organic matter. However, the aerobic respiration of the polychaetes partly contributes to the increased oxygen uptake found in the presence of polychaetes. The observed reduced number of holes dug in the sediment by the polychaetes in the presence of shells in the sediment could potentially be one explanation for the observed reduced weight loss among the polychaetes in the same sediment, as reduced digging behaviour and a more sedentary behaviour are expected to reduce the energy requirement of the polychaetes. In order to explain the data we obtained (e.g. increased release of ammonium), other polychaete activities, such as irrigation of their burrows, must have taken place. Another possible explanation for the reduced number of holes would be that $H$. diversicolor utilize the microbiome on the sediment as a food source and thus spend less energy searching for food in the sediment, resulting not only in fewer holes but also in reduced polychaete weight loss.

Increased release rates of ammonium and phosphate are generally observed in sediments beneath aquaculture structures compared to sediments at control sites (Giles \& Pilditch 2006, Nizzoli et al. 2006, Thouzeau et al. 2007), as the sediment becomes more 
reduced due to decomposition of organic matter. This causes shifts in nutrient cycling, meaning less ammonium turns into nitrate which can then be denitrificated. Reduced (i.e. less oxidized) conditions in the sediment also mobilize phosphate from iron phosphates releasing phosphate from the sediment. This increased release rate could, according to the results from this study, be in excess to the effects caused by an increased degradation of organic matter and stimulation of aerobic microbial activity by bioturbation (Nizzoli et al. 2007). It could also be partly due to a higher amount of mussel shells in the sediment underneath the mussel farms compared to outside the farms, as the presence of shells enhanced both the release of ammonium and of phosphate as was shown in this study.

The observed increased release of phosphate from the sediment can potentially be a consequence of the release of phosphate from phosphate-containing mucus linings of burrows, as has previously been observed for other nereidid polychaete species (Kristensen 2000). Berezina et al. (2019) suggested that phosphate efflux from oxygenated sediments can be mediated by benthic animals through excretion and their bioturbation and bioirrigation, which was observed by Biswas et al. (2017). In addition to this potential route for phosphate release through the mucus lining, the mucus produced by the polychaetes may also increase ammonium released from the sediment by stimulation of archaeal ammonia oxidizers as shown by Dale et al. (2019). Ammonium release though extraction by the polychaete may also make a contribution. Furthermore, oxygen supplied through the burrows might affect organic phosphate matter in sediments (Waldbusser et al. 2004), mobilizing organic phosphate and releasing inorganic phosphate to the water and increasing phosphate efflux in a way similar to that observed here and as observed for ammonium release upon recolonization by H. diversicolor (Hansen \& Kristensen 1997).

Through their bioturbation, $H$. diversicolor promote transportation of fresh organic particles from the sediment surface into their burrows deeper in the sediment. This together with microbial-mediated mineralization increases the decomposition rate of organic matter, and this decomposition rate can, as indicated by the results in this study, be partly facilitated by the presences of mussel shells in the sediment which help create pockets of microhabitats suitable for these processes in the sediment. It has previously been suggested that bioturbation can break the dynamic balance of nitrification and denitrification, thus changing the nitrogen cycling rates over the sediment-water surface as was observed for clam bioturbation by Zhao et al. (2019) and Zhang et al. (2020). However, we could not find any clear evidence for this in our study. Bioturbation increases the sediment-surface water interface and the oxidized sediment surface layer resulting in increased nitrification (Kristensen 1984) and accelerates the transportation of nitrate to the sediment-water interface, but in this study we did not observe a significant change in nitrate fluxes in the presence of $H$. diversicolor in either the presence or absence of mussel shells or when adding organic matter to the sediment.

In conclusion, this study illustrates the importance of taking deposition and accumulation of shells from mussel farms on the sediment surface into account when considering bioturbation as potential mitigation efforts of the organic enrichment under mussel farms. Here we show that the presence of shells in the sediment tends to stimulate bioturbation effects on sediment-water fluxes and that, even though more studies and technological solutions are needed, the idea of using bioturbating polychaetes in mitigation efforts of organically enriched sediments affected by organic matter from mussel farms is worth pursuing.

Acknowledgements. This study was funded by the Swedish Agency for Marine and Water Management, contract no. 4356-2016, as part of the BONUS project 'OPTIMUS - Optimization of Mussel mitigation culture for fish feed in the Baltic Sea'. We are grateful to Thore Hilmersson for his help in building the incubation system.

\section{LITERATURE CITED}

Aller RC (1994) Bioturbation and remineralization of sedimentary organic matter: effects of redox oscillation. Chem Geol 114:331-345

Aller RC (2001) Transport and reactions in the bioirrigated zone. In: Boudreau BP, Jørgensen BB (eds) The benthic boundary layer. Oxford University Press, New York, NY, p 269-301

Aller RC, Aller JY, Kemp PF (2001) Effects of particle and solute transport on rates and extents of remineralization in bioturbated sediments. In: Aller JY, Aller RC, Woodin $\mathrm{S}$ (eds) Organism-sediment interaction. University of South Carolina Press, Columbia, SC, p 315-333

*Berezina NA, Maximov AA, Vladimirova OM (2019) Influence of benthic invertebrates on phosphorus flux at the sediment-water interface in the easternmost Baltic Sea. Mar Ecol Prog Ser 608:33-43

Bergström P, Carlsson MS, Lindegarth M, Petersen JK, Lindegarth S, Holmer M (2017) Testing the potential for improving quality of sediments impacted by mussel farms using bioturbating polychaete worms. Aquacult Res 48:161-176

Bergström P, Hällmark N, Larsson KJ, Lindegarth M (2019) Biodeposits from Mytilus edulis: a potentially highquality food source for the polychaete, Hediste diversicolor. Aquacult Int 27:89-104 
Bernard G, Gammal J, Järnström M, Norkko J, Norkko A (2019) Quantifying bioturbation across coastal seascapes: habitat characteristics modify effects of macrofaunal communities. J Sea Res 152:101766

Biswas JK, Hazra S, Majumdar J, Mandal SK, and others (2017) Impact of raking and bioturbation-mediated ecological manipulation on sediment-water phosphorus diagenesis: a mesocosm study supported with radioactive signature. Environ Geochem Health 39:1563-1581

Burkholder JM, Shumway SE (2011) Bivalve shellfish aquaculture and eutrophication. In: Shumway SE (ed) Shellfish aquaculture and the environment. Wiley-Blackwell, Hoboken, NJ, p 155-215

Caliman A, Leal JJF, Esteves FA, Carneiro LS, Bozelli RL, FarjallaVF (2007) Functional bioturbator diversity enhances benthic-pelagic processes and properties in experimental microcosms. J N Am Benthol Soc 26:450-459

* Carlsson MS, Holmer M, Petersen JK (2009) Seasonal and spatial variations of benthic impacts of mussel longline farming in a eutrophic Danish fjord, Limfjorden. J Shellfish Res 28:791-801

* Carlsson MS, Engstrom P, Lindahl O, Ljungqvist L, Petersen JK, Svanberg L, Holmer M (2012) Effects of mussel farms on the benthic nitrogen cycle on the Swedish west coast. Aquacult Environ Interact 2:177-191

* Casado-Coy N, Martínez-García E, Sánchez-Jerez P, SanzLázaro C, Rohr J (2017) Mollusc-shell debris can mitigate the deleterious effects of organic pollution on marine sediments. J Appl Ecol 54:547-556

Casado-Coy N, Sanchez-Jerez P, Holmer M, Sanz-Lazaro C (2020) Bioturbation may not always enhance the metabolic capacity of organic polluted sediments. Mar Environ Res 155:104882

Choi YD (2007) Restoration ecology to the future: a call for new paradigm. Restor Ecol 15:351-353

* Christensen PB, Glud RN, Dalsgaard T, Gillespie P (2003) Impacts of longline mussel farming on oxygen and nitrogen dynamics and biological communities of coastal sediments. Aquaculture 218:567-588

* Cloern JE (2001) Our evolving conceptual model of the coastal eutrophication problem. Mar Ecol Prog Ser 210: 223-253

Commito JA, Como S, Grupe BM, Dow WE (2008) Species diversity in the soft-bottom intertidal zone: biogenic structure, sediment, and macrofauna across mussel bed spatial scales. J Exp Mar Biol Ecol 366:70-81

* Cranford PJ, Duarte P, Robinson SMC, Fernandez-Reiriz MJ, Labarta U (2014) Suspended particulate matter depletion and flow modification inside mussel (Mytilus galloprovincialis) culture rafts in the Ria de Betanzos, Spain. J Exp Mar Biol Ecol 452:70-81

Dale H, Taylor JD, Solan M, Lam P, Cunliffe M (2019) Polychaete mucopolysaccharide alters sediment microbial diversity and stimulates ammonia-oxidising functional groups. FEMS Microbiol Ecol 95, doi:10.1093/femsec/ fiy234

de Mendiburu F (2019) agricolae: statistical procedures for agricultural research. R package version 1.3-1. http:// tarwi.lamolina.edu.pe/ fmendiburu

* Denny MW, Blanchette CA (2000) Hydrodynamics, shell shape, behavior and survivorship in the owl limpet Lottia gigantea. J Exp Biol 203:2623-2639

Diaz RJ, Rosenberg R (2008) Spreading dead zones and consequences for marine ecosystems. Science 321: 926-929
Duarte CM, Conley DJ, Carstensen J, Sanchez-Camacho M (2009) Return to Neverland: shifting baselines affect eutrophication restoration targets. Estuaries Coasts 32: 29-36

* Evrard V, Huettel M, Cook PLM, Soetaert K, Heip CHR, Middelburg JJ (2012) Importance of phytodetritus and microphytobenthos for heterotrophs in a shallow subtidal sandy sediment. Mar Ecol Prog Ser 455:13-31

* Gilbert F, Aller RC, Hulth S (2003) The influence of macrofaunal burrow spacing and diffusive scaling on sedimentary nitrification and denitrification: an experimental simulation and model approach. J Mar Res 61:101-125

Giles H, Pilditch CA (2006) Effects of mussel (Perna canaliculus) biodeposit decomposition on benthic respiration and nutrient fluxes. Mar Biol 150:261-271

*Gutierrez JL, Jones CG, Strayer DL, Iribarne OO (2003) Mollusks as ecosystem engineers: the role of shell production in aquatic habitats. Oikos 101:79-90

*Hansen K, Kristensen E (1997) Impact of macrofaunal recolonization on benthic metabolism and nutrient fluxes in a shallow marine sediment previously overgrown with macroalgal mats. Estuar Coast Shelf Sci 45:613-628

Heilskov AC, Holmer M (2003) Influence of benthic fauna on organic matter decomposition in organic-enriched fish farm sediments. Vie Milieu 53:153-161

HELCOM (2007) The Baltic Sea Action Plan. Helsinki Commission (HELCOM) Baltic Marine Environment Protection Commission, Helsinki

ํHewitt JE, Thrush SF, Halliday J, Duffy C (2005) The importance of small-scale habitat structure for maintaining beta diversity. Ecology 86:1619-1626

* Howe RL, Rees AP, Widdicombe S (2004) The impact of two species of bioturbating shrimp (Callianassa subterranea and Upogebia deltaura) on sediment denitrification. J Mar Biol Assoc UK 84:629-632

*Hulth S, Aller RC, Canfield DE, Dalsgaard T, and others (2005) Nitrogen removal in marine environments: recent findings and future research challenges. Mar Chem 94: 125-145

Kemp WM, Boynton WR, Adolf JE, Boesch DF and others (2005) Eutrophication of Chesapeake Bay: historical trends and ecological interactions. Mar Ecol Prog Ser 303:1-29

Komsta L (2011) outliers: tests for outliers. R package version 0.14. https://CRAN.R-project.org/package=outliers

* Kotta J, Futter M, Kaasik A, Liversage K and others (2020) Cleaning up seas using blue growth initiatives: mussel farming for eutrophication control in the Baltic Sea. Sci Total Environ 709:136144

Kristensen E (1984) Effect of natural concentrations on nutrient exchange between a polychaete burrow in estuarine sediment and the overlying water. J Exp Mar Biol Ecol 75:171-190

Kristensen E (2000) Organic matter diagenesis at the oxic/ anoxic interface in coastal marine sediments, with emphasis on the role of burrowing animals. Hydrobiologia 426: $1-24$

Kristensen E, Kostka JE (2005) Macrofaunal burrows and irrigation in marine sediment: microbiological and biogeochemical interactions. In: Kristensen E, Haese RR, Kostka JE (eds) Interactions between macro- and microorganisms in marine sediments. American Geophysical Union, Washington, DC, p 125-157

KLaverock B, Gilbert JA, Tait K, Osborn AM, Widdicombe S (2011) Bioturbation: impact on the marine nitrogen cycle. Biochem Soc Trans 39:315-320 
Lindahl O, Hart R, Hernroth B, Kollberg S and others (2005) Improving marine water quality by mussel farming: a profitable solution for Swedish society. Ambio 34:131-138

Mattsson J, Lindén O (1983) Benthic macrofauna succession under mussels, Mytilus edulis L. (Bivalvia), cultured on hanging long-lines. Sarsia 68:97-102

Mermillod-Blondin F, Rosenberg R, Francois-Carcaillet F, Norling K, Mauclaire L (2004) Influence of bioturbation by three benthic infaunal species on microbial communities and biogeochemical processes in marine sediment. Aquat Microb Ecol 36:271-284

Meysman FJR, Middelburg JJ, Heip CHR (2006) Bioturbation: a fresh look at Darwin's last idea. Trends Ecol Evol 21:688-695

Michaud E, Desrosiers G, Mermillod-Blondin F, Sundby B, Stora G (2005) The functional group approach to bioturbation: the effects of biodiffusers and gallery-diffusers of the Macoma balthica community on sediment oxygen uptake. J Exp Mar Biol Ecol 326:77-88

Nielsen OI, Gribsholt B, Kristensen E, Revsbech NP (2004) Microscale distribution of oxygen and nitrate in sediment inhabited by Nereis diversicolor: spatial patterns and estimated reaction rates. Aquat Microb Ecol 34: 23-32

Nixon SW (1995) Coastal marine eutrophication - a definition, social causes, and future concerns. Ophelia 41: 199-219

Nizzoli D, Bartoli M, Viaroli P (2006) Nitrogen and phosphorous budgets during a farming cycle of the Manila clam Ruditapes philippinarum: an in situ experiment. Aquaculture 261:98-108

Nizzoli D, Bartoli M, Cooper M, Welsh DT, Underwood GJC, Viaroli P (2007) Implications for oxygen, nutrient fluxes and denitrification rates during the early stage of sediment colonisation by the polychaete Nereis spp. in four estuaries. Estuar Coast Shelf Sci 75:125-134

Norling K, Rosenberg R, Hulth S, Grémare A, Bonsdorff E (2007) Importance of functional biodiversity and speciesspecific traits of benthic fauna for ecosystem functions in marine sediment. Mar Ecol Prog Ser 332:11-23

Olivera AM, Wood WL (1997) Hydrodynamics of bivalve shell entrainment and transport. J Sediment Res 67:514-526

Pelegri SP, Blackburn TH (1995) Effect of bioturbation by Nereis sp., Mya arenaria and Cerastoderma sp. on nitrification and denitrification in estuarine sediments. Ophelia 42:289-299

Petersen JK, Hansen JW, Laursen MB, Clausen P, Carstensen J, Conley DJ (2008) Regime shift in a coastal marine ecosystem. Ecol Appl 18:497-510

* Petersen JK, Hasler B, Timmermann K, Nielsen P, Torring DB, Larsen MM, Holmer M (2014) Mussels as a tool for mitigation of nutrients in the marine environment. Mar Pollut Bull 82:137-143

R Core Team (2019) R: a language and environment for statistical computing. Version 3.6.2. R Fundation for Statistical Computing, Vienna

R Studio Team (2019) RStudio: integrated development for R. RStudio, Boston, MA

Editorial responsibility: Pablo Sánchez Jerez, Alicante, Spain
Ragnarsson SÁ, Raffaelli D (1999) Effects of the mussel Mytilus edulis L. on the invertebrate fauna of sediments. J Exp Mar Biol Ecol 241:31-43

Reise K (2002) Sediment mediated species interactions in coastal waters. J Sea Res 48:127-141

Richard M, Archambault P, Thouzeau G, McKindsey CW, Desrosiers G (2007) Influence of suspended scallop cages and mussel lines on pelagic and benthic biogeochemical fluxes in Havre-aux-Maisons Lagoon, Iles-dela-Madeleine (Quebec, Canada). Can J Fish Aquat Sci 64:1491-1505

* Riisgard HU (1991) Suspension feeding in the polychaete Nereis diversicolor. Mar Ecol Prog Ser 70:29-37

Riisgård HU, Kamermans P (2001) Switching between deposit and suspension feeding in coastal zoobenthos. In: Reise $\mathrm{K}$ (ed) Ecological comparisons of sedimentary shores. Springer, Berlin, p 73-101

Kydin E, Kumblad L, Wulff F, Larsson P (2017) Remediation of a eutrophic bay in the Baltic Sea. Environ Sci Technol 51:4559-4566

* Rysgaard S, Christensen PB, Nielsen LP (1995) Seasonal variation in nitrification and denitrification in estuarine sediment colonized by benthic microalgae and bioturbating infauna. Mar Ecol Prog Ser 126:111-121

Schroder T, Stank J, Schernewski G, Krost P (2014) The impact of a mussel farm on water transparency in the Kiel Fjord. Ocean Coast Manage 101:42-52

Stief P (2013) Stimulation of microbial nitrogen cycling in aquatic ecosystems by benthic macrofauna: mechanisms and environmental implications. Biogeosciences 10: 7829-7846

* Thouzeau G, Grall J, Clavier J, Chauvaud L and others (2007) Spatial and temporal variability of benthic biogeochemical fluxes associated with macrophytic and macrofaunal distributions in the Thau lagoon (France). Estuar Coast Shelf Sci 72:432-446

Tuominen L, Mäkelä K, Lehtonen KK, Haahti H, Hietanen S, Kuparinen J (1999) Nutrient fluxes, porewater profiles and denitrification in sediment influenced by algal sedimentation and bioturbation by Monoporeia affinis. Estuar Coast Shelf Sci 49:83-97

Valdemarsen T, Kristensen E, Holmer M (2010) Sulfur, carbon, and nitrogen cycling in faunated marine sediments impacted by repeated organic enrichment. Mar Ecol Prog Ser 400:37-53

*Waldbusser GG, Marinelli RL, Whitlatch RB, Visscher PT (2004) The effects of infaunal biodiversity on biogeochemistry of coastal marine sediments. Limnol Oceanogr 49:1482-1492

* Zhang S, Fang X, Zhang J, Yin F, Zhang H, Wu L, Kitazawa $\mathrm{D}$ (2020) The effect of bioturbation activity of the ark clam Scapharca subcrenata on the fluxes of nutrient exchange at the sediment-water interface. J Ocean Univ China 19:232-240

Zhao L, Zheng YQ, Nicholaus R, Lukwambe B, Zhu JY, Yang W, Zheng ZM (2019) Bioturbation by the razor clam Sinonovacula constricta affects benthic nutrient fluxes in aquaculture wastewater treatment ecosystems. Aquacult Environ Interact 11:87-96

Submitted: March 30, 2020; Accepted: June 3, 2020

Proofs received from author(s): July 16, 2020 